木造重要文化財建造物の耐震補強における意思決定プロセスに関する研究 一構造設計者の役割を中心として一

\title{
A STUDY ON THE DECISION MAKING PROCESS OF SEISMIC STRENGTENING OF WOODEN IMPORTANT CULTURAL PROPERTIES \\ - Focusing on the role of structural engineers-
}

\author{
角陸順香*, 清家 剛**, 藤田香織***, 宇野縉 晴**** \\ Yorika KADORIKU, Tsuyoshi SEIKE, Kaori FUJITA \\ and Yoshiharu UNO
}

\begin{abstract}
The purpose of this paper is to reveal the decision making process during the seismic strengthening work of important cultural properties. The authors interviewed structural engineers who were involved in the seismic strengthening of wooden important cultural properties after the Great Hanshin-Awaji Earthquake in 1995. Through analyzing:

1. The principle and decision making process of the structural engineer.

2. The demands from other parties to the structural engineer and derivative issues.

the general process and problems of seismic strengthening are clarified. In conclusion an ideal methodology of the seismic strengthening process of wooden important cultural properties is proposed.
\end{abstract}

Keywords: wooden structure, important cultural properties, seismic strengtening, structural design, decision making process

木造, 重要文化財, 耐震補強, 構造設計, 意思決定プロセス

\section{1. 研究の背景と目的}

文化財建造物の保存修理とは、その建物の文化財的価值を後世に 残すために、一般には建設当初の形への復原を目指すものである。 しかし平成 7 年の阪神淡路大震炎以後、文化財といえども人が立ち 入る以上、人命の保護が必要であるとの認識がより強まり、本格的 な耐震補強が行われるようになってきた。文化庁でも、「重要文化財 （建造物）耐震診断指針」(平成 12 年）a)及び同参考資料集b)を発行 し、特に安全性確保についての指針を示している。

重要文化財建造物の耐震補強設計における意思決定は、通常の建 築における改修の場合とは異なり特有な形態を持つ。なぜなら文化 財的価值を損なわず、可能な限り安全性を確保せねばならないため である。そこには設計監理者をはじめ、構造設計者、所有者、構造 や歷史の有識者など異なる価值観を持った人々が関わり、これら 様々な主体(1)間での意思蹯通はどのように行われ、どんな問題点が 生じうるのかを把握し、各主体が耐震補強に対してどう臨むべきで あるかを明らかにすることは重要である。なかでも建物の力学的特 性や構造に関する知識、技術を提供する構造設計者は、耐震補強工 事の意思決定プロセスにおいて中心的な役割を担っている。なぜな ら、国宝・重要文化財建造物は建築基準法第 3 条によりその摘要除 外を受けているため、満たすべき構造性能の目慗值は当該建造物の 用途、文化財としての価值、使用頻度等を鑑みて個別に判断できる、 と同時に判断が必要になるが、これには高度かつ専門的な構造設計 の知識が要求されるからである。以上より、各意思決定主体がどう 構造設計者と関わっているのかを明らかにする事により、耐震補強 工事の進め方や各段階で検討すべき事柄が明確になると考えられる。
歴史的な建物の保存に関する研究はこれまで広く行われているが、 文化財建造物の耐震補強に関連する既往研究は、材料・部材、接合 部、組物、構面、または建物全体に関する実験的研究など構造的特 性に着目したものが多く(d) (ng)：この分野での研究は着実に蓄積さ れてきていると言える。その中において、阪神淡路大震災による文 化財建造物の被害の状況と復旧の実態を調査した研究へがあるが、 主に補強技術や助成制度に目が向けられており、耐震性の向上と オーセンティシティの尊重の兼ね合いについて触れてはいるが、各 専門家間の意思決定プロセスにおける関わり方については具体的に 述べられていない。このように、本研究のような意思决定プロセス に着目した研究は未だなされていない。

筆者等はこれまで、阪神淡路大震災以降、平成 12 年までに耐震 診断の依頼を受けた国指定木造重要文化財建造物で文化財建造物保 存技術協会 (以下、文建協)が設計監理を行った 33 事例についてデー タシートの作成を行い、さらにデータベースに基づいた構造設計者 に対するヒアリング調查により、構造設計者から見た耐震補強の意 思決定に関する調查を行った。(12)334)5)また、継続して意思決定プロセ スにおいて生じる要望や問題点について整理し分析を行った。

本研究では、木造重要文化財建造物の耐震補強事例についての構 造設計者に対するヒアリング調查を基に(1)構造設計者の立場からの 耐震補強に対する考え方や意思决定のプロセス，生じた要望や問題 点等を明らかにして耐震補強全体の流れを捉える事(2)耐震性能の点 から耐震補強設計の現状を分析して、今後の課題を明らかにする事、 (3)全体を通しての諸問題を分析することによって、今後の木造文化 財建造物の耐震補強設計の在り方を提案する事を目的としている。
東京大学大学院新領域創成科学研究科環境学尃攻 博士課程・修士(環境学)

* 東京大学大学院新領域刢成科学研究科環境学専攻 助教授 · 搏士 (工学)

*** 東京都立大学大学院工学研究科建築学専攻 講師 . 博士 (

**** (侏三菱地所設計 修士(環境学)
Graduate School of Frontier Sciences, the Univ. of Tokyo, M. Eng.

Assoc. Prof., Graduate School of Frontier Sciences, the Univ. of Tokyo, Dr. Eng Assist. Prof., Department of Eng., Tokyo Metropolitan Univ., Dr. Eng. Graduate School of Frontier Sciences, the Univ. of Tokyo, M. Eng. 


\section{2. 調查対象・方法}

調查の対象は、前述の 33 事例である（表 1 )。

これらの事例について、耐震診断・構造設計を手がけた構造設計 事務所 11 社の協力を得て、耐震補強設計の過程における構造設計 者の考え方や取り組み方: 生じた問題点や他の主体からの要望を中 心に、ヒアリング調查（期間 : 平成 13 年 9 月〜 11 月）を行った。

\section{3. 各段階での検討内容の分析}

調查結果をもとに、耐震補強における意思決定において生じうる プロセスを全てまとめると、およそ下の図 1 に示すような流れであ ることがわかった。ここでのプロセスとは「実際におこる依頼、調 査、設計、工事の流れ全体」をさす。実際の意思決定においては様々 な変更や修正、フィードバックが生じており、各事例のプロセスは 個別性が高く複雑なものであったが、図 1 では、意思決定の流れを 出来るだけわかり易くする事を目的として、ポイントとなる項目を あげ、大まかな基本となるパターンとしてまとめている。調査では、 全事例においてそれぞれのプロセスに関して変更等を含め、各段階 における要望や問題点を中心に整理した概略図を作成した。

また、本論で焦点を当てている耐震補強は、あくまで文化財の修 理工事の一瑻である。基本的には、経年劣化により修復が必要と なった事例から、震災による倒壊などの被害を受けた建物の事例も 含めて、本来の文化財修理工事全体の流れの中での構造補強、とい う位置付けであるので、修理工事全体の進行と関連づけて論述する べきであるが、本論は構造設計者からの視点を中心に、という立場 をとっていること、また耐震補強は通常の修理工事で扱われる、非 構造部材以外のおおかたの項目（屋根、柱、壁等）を含んでいるこ と、文化財の修理工事に関する情報の蓄積はある程度為されて来て いるが耐震補強の急増は近年の動きで、まだ知識や技術、手法が確 立されていないことなどの理由により、まずは耐震補強のプロセス に絞って論を進めることとする。しかし、補強方針を定める上で何 が重文指定を受けているのか、によって採用しうる工法が決定する 場合があるなど、修理工事全体と耐震補強の進行の関連は重要であ るので、今後継続して調査を深めたい。

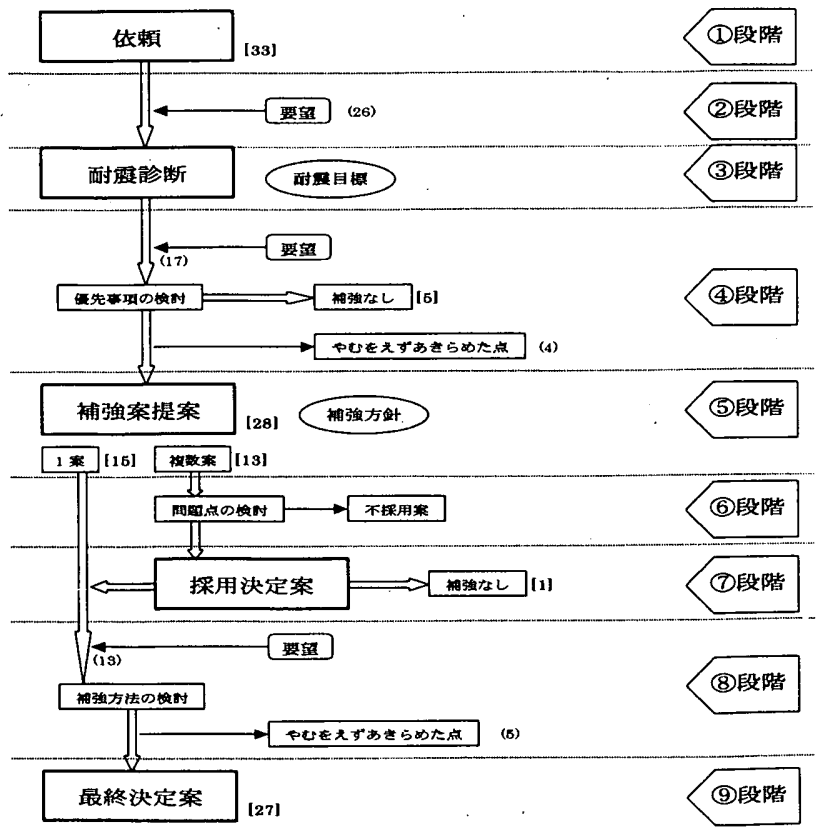

図 1 酎震補强における意思決定の基本的な流れ

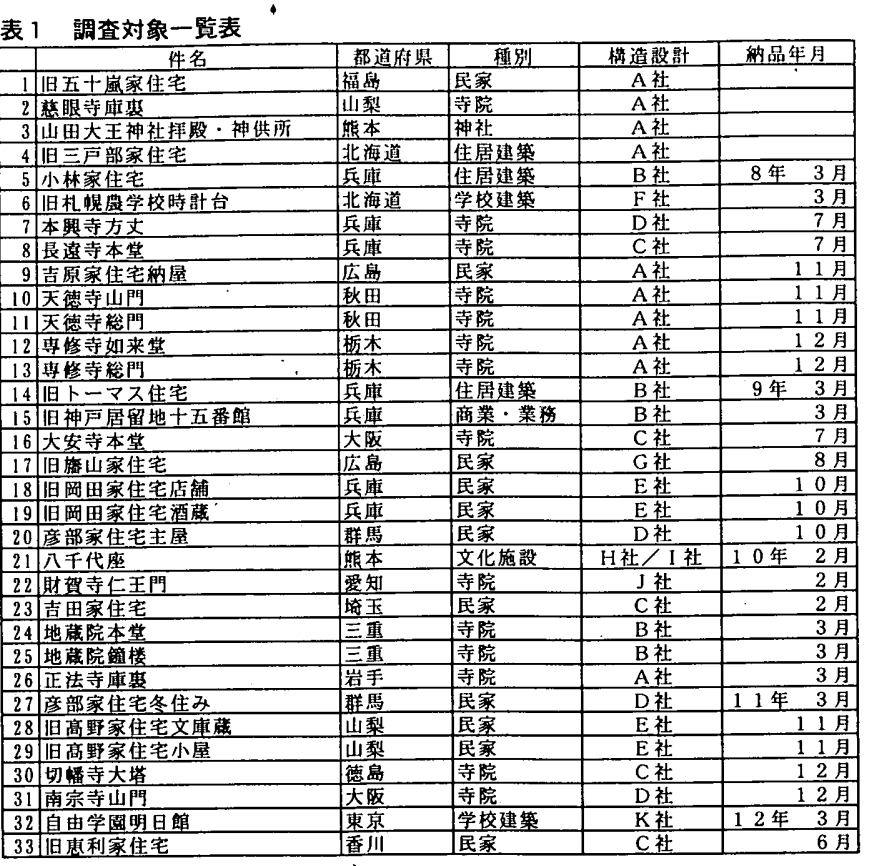

耐震補強における意思決定の基本的な流れは図 1 に示したように 13 の段階に分けることができると考えた。以下に、検討が行われ る 7 つの段階で、対象事例において行われた内容の分析について述 ベる。

3-1. 基本設計段階（1)～(9)段階）

(2)段階

まず、耐震診断の依頼に伴い、診断を行うに当たっての要望が生 じていた。ここでは、「当初の姿に戻して欲しい」、「外観を残して欲 しい」など補強の概要に関わるものが中心となっていて、保存修理 工事全体における基本コンセプトを設定する段階であるといえる。 ここに挙げている項目は、初期の段階において、各主体がそれぞれ の要望を提示するもので、様々な技術要件をふまえた総合的な表現 となっている。(表 2 )

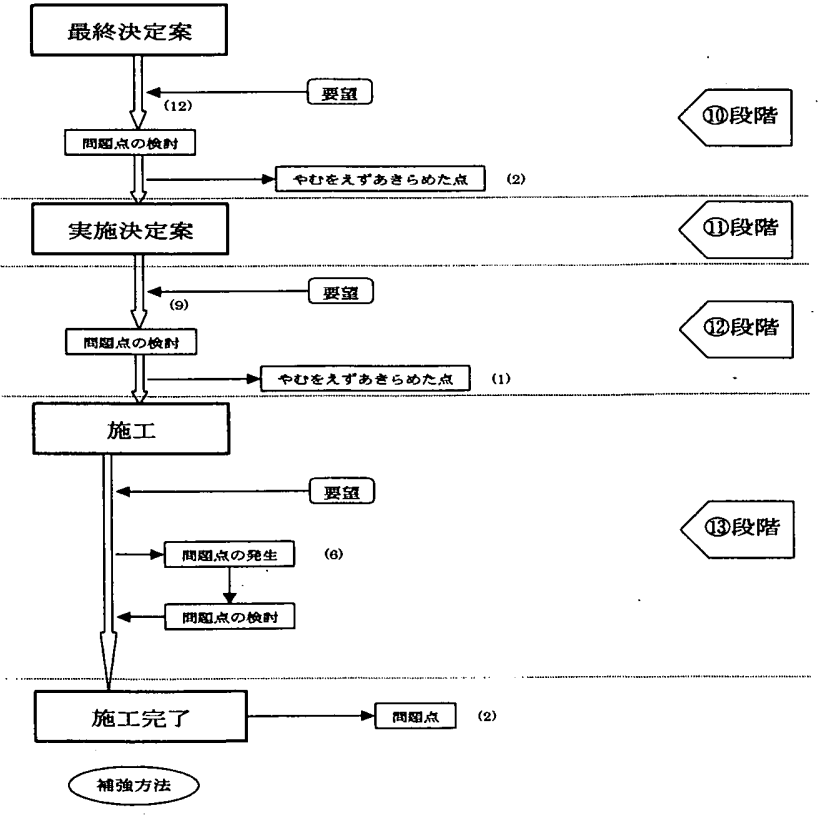


表 2 (2)段階での要望のうち、補強の摡要に関するもの (要望のあった事例数 : 16、要望絰数 : 20)

\begin{tabular}{|l|c|}
\hline \multicolumn{1}{|c|}{ 要望内容 } & 該当数 \\
\hline 当初の姿に戻す & 6 \\
\hline 外観を残す & 4 \\
\hline できるだけ手を加えない & 2 \\
\hline 全体を残す & 1 \\
\hline 筞畻気を残す & 1 \\
\hline 内観を残す & 1 \\
\hline 文化財としての価値を残す & 1 \\
\hline 全体の構造強度のレベルを上げる & 1 \\
\hline 大規模な補強にしない & 1 \\
\hline 震災復興のシンボルにする[神戸市] & 1 \\
\hline 本物にする & 1 \\
\hline
\end{tabular}

\section{(4)段階}

耐震診断ののちに、耐震性能の不足するものは補強案の検討へ、 概ね耐震性能の認められたものは、この段階で補強なしと決まって いた。調查対象 33 件のうち、最終的に補強を行わなかった事例は 6 件あるが、うち 5 件はこの段階で決定していた。

補強案を作成するに当たっては各種の要望があり、一般的には、 補強に対する基本方針を考え、耐震性能の目標值を設定し、それに 従って案を作成する流れとなっていた。ここで補強案の検討を行っ た 28 件について方鍄して考慮した点を調查し整理した。（表 3 ）

\section{表 3 補强方針 (総数: 28)}

\begin{tabular}{|l|c|}
\hline \multicolumn{1}{|c|}{ 方針の内容 } & 覀当数 \\
\hline 人命を保護する & 22 \\
\hline 文化財的価值を摜なわないようにする & 21 \\
\hline 補強部材・部品が見えないようにする & 23 \\
\hline 禣強部材を取り外し可能にする & 18 \\
\hline 既存部材を使用する & 17 \\
\hline 既存部材を傷めない & 14 \\
\hline 建物の工法を保存する & 14 \\
\hline 建物の力学系を変えない & 6 \\
\hline
\end{tabular}

また、補強方針及び補強の有無に大きく影響する項目としては、 建物の使用条件が挙げられていた。建物の使用条件のレベル設定を 行って整理すると、 33 件中 26 件と殆どの建物で常時人の利用が あることを想定しており (表 4)、このことも補強方針を定める上で 「人命の保護」を重要視する理由となっていると考えられる。

\section{表 4 建物の使用条件 (数数: 33)}

\begin{tabular}{|c|c|}
\hline 使用条件のレベル & 㽬当数 \\
\hline 常時人の利用がある. & 26 \\
\hline 使用する人もしくは使用する時期が限られている & 4 \\
\hline 公開しない、人の使用する頻度は極めて少ない & 3 \\
\hline
\end{tabular}

しかし、表 3 に挙げた方針を全て満たすような補強は、文化財建 造物の場合は容易ではなく、個々の建物について何を優先させるの かを十分に検討しなければならない。その過程では、これらの方針 に従うことのできない部分もあり、優先度の低い項目に関しては、 やむをえずあきらめるという判断も生じていた。また、この段階で の要望はこれらの方針に関わるものが主となっていた（表 5 ）。

表 5 (4)段陕での要望のうち、補强方針に対するもの (要望のあった电例数 $: 7$ 、要望格数 : 11 )

\begin{tabular}{|l|c|}
\hline \multicolumn{1}{|c|}{ 要望内容 } & 該当数 \\
\hline 補強が見えないように & 4 \\
\hline 既存部材を甥めないように & 2 \\
\hline 構造体の入れ替えをしないように & 2 \\
\hline 将来全解体せずに撤去できるように & 1 \\
\hline 人が入ることを考するように & 1 \\
\hline 本物になるように & 1 \\
\hline
\end{tabular}

\section{6段階}

補強案を複数提案した場合には、そこから1つに絞り込む段階が あり、ここでは基本的には上記の方針として定めたものに反する案、 例えば「補強が見えてしまう」「既存部材を傷めてしまう」といった 案が不採用となっていた。(表6)

表 6 (6)段陼ての不採用案の理由で補強方針に関するもの（例数: 8、粉数：11)

\begin{tabular}{|l|c|}
\hline \multicolumn{1}{|c|}{ 不探用の理由 } & 硋当数 \\
\hline 補強が見えてしまう & 4 \\
\hline 既存部材を第める & 3 \\
\hline 在来工法を摜なう & 1 \\
\hline 構造体の入れ替えを行っている & 1 \\
\hline 必要最低限の補強のため & 1 \\
\hline システムが変わりすぎる & 1 \\
\hline
\end{tabular}

\section{8)段階}

ここではさらに具体的な「取り外しのできる工法を」「できるだけ 旧材を用いる」といつた補強方針への要望（表 7 )や、「耐力の不足」 「壁量の不足」のような耐震目標に関わる問題点（表 8 ）が挙げられ ており、補強方針や耐震目標に反している部分は、それらを満足で きるように修正されて、最終決定案に至っていた。

\section{表 7 இ段階での要望のうち、補強方針に関するもの}

(要望のあった車例数 : 7、要望校数 : 11)

\begin{tabular}{|l|c|}
\hline \multicolumn{1}{|c|}{ 要望内容 } & 該当数 \\
\hline 補強が見えないように & 3 \\
\hline 取り外しのできる工法を & 2 \\
\hline 必要最低限の補強を & 1 \\
\hline 後からわかるような補強を & 1 \\
\hline 取り付け位置は公開しない部分に & 1 \\
\hline 補強楥和の要望（鉄骨フレームの形状） & 1 \\
\hline できるだけ旧材を用いる & 1 \\
\hline 公開部に補強が露出しないように & 1 \\
\hline
\end{tabular}

\section{表 8 (8)段階での問題点のうち、耐震目標に関するもの}

(問題のあった車例数 : 7 、問題点総数 : 7)

\begin{tabular}{|l|c|}
\hline \multicolumn{1}{|c|}{ 問題点 } & 該当数 \\
\hline 実験による耐力不足（土壁） & 1 \\
\hline 重量不足（免震化のため） & 1 \\
\hline 解体後、基礎のレベルが下がっている事がわかる & 1 \\
\hline ねじれによる崩壊の防此の必要性 & 1 \\
\hline 地盤固定補強支柱の応力集中 & 1 \\
\hline 耐力の不足 & 1 \\
\hline 壁量の不足 & 1 \\
\hline
\end{tabular}

\section{3-2. 実施設計段階（9～(13)段階)}

(10)段階

最終決定案を実際に施工する為には、「配管・配線が納まらない」 「柱端部が浮き上がる」などの問題が生じ（表 9 ) ティテールを中心 とした変更を行う段階を経て、実施案が決まっていた。

表 9 『段階での補强方法に関する問題点（問題のあった車例数 : 5、問題点粉数 : 10)

\begin{tabular}{|c|c|}
\hline 問題点 & 咳当数 \\
\hline 配管・配線の納まりの問題 & 2 \\
\hline 柱端部の浮き上がりの問題 & 1 \\
\hline 結絧の問題 & 1 \\
\hline 冬期積雪荷重の問題 & 1 \\
\hline 免震層が50cm動く & 1 \\
\hline 免震ゴムの性質上の問題 & 1 \\
\hline 壁厚が厚くなってしまう & 1 \\
\hline 納まらない部分の調整 & 1 \\
\hline 免震層活用方法の問題 & 1 \\
\hline
\end{tabular}


(1)段階

実施決定案を施工するに当たって、現場で紐かい部分の調整等を 行っていた。ここでは「部材の分割が必要」「部材の置き場所の確保」 「必要なサイズの合板を輸入」「遺跡に当たっていた」などといった 個別性の高い問題点が多かったが、下記に挙げるような事前に検討 可能な項目も多いといえる。

〈事前に検討可能な項目〉
a. 接合部材の変更
b. 接合方法（ボルト/溶接など）
c. 部材の置き場所
e. 部材搬入の問題
f. 地中埋藏物の確認
g. 結露対策

d. 部材のサイズの確認

(13)段階

施工中には、「文化財建造物の工事に慣れていない施工業者に対す る技術指導が必要になる」「部材や接合部に問題が発生」などといっ た施工上の問題や、「現場に持ち込むのに苦労」「現場組立に困難を 伴う」などの搬入上の問題が生じることがあった。（表 10)

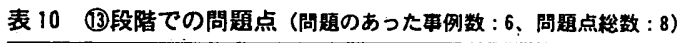

\begin{tabular}{|c|l|c|}
\hline \multicolumn{2}{|c|}{ 問題点 } & 硋当数 \\
\hline \multirow{4}{*}{ 施工上の問題 } & 施工業者の技術指導 & 3 \\
\cline { 2 - 3 } & バネルにたかみ発生、調整 & 1 \\
\cline { 2 - 3 } & 溶接長さが足りない場溶接、注意が必要 & 1 \\
\hline \multirow{2}{*}{ 搬入上の問題 } & 現場に持ち込むのに苦学 & 1 \\
\cline { 2 - 3 } & 現場で組む時に困難を伴う & 1 \\
\hline
\end{tabular}

実際に施工となる(12)段階、(13)段階では、接合部や部材搬入などの 共通する問題も含め、もっと早い段階で検討しておけば、生じる問 題を極力軽減できる項目も多いことがわかった。これらの問題をど の段階で検討すべきか整理しておくことが必要であると考えられる。 3-3. 各段階検討内容の分析のまとめ

事例により、あまり問題もなく順調に進行していたものもあれば、 そうでないものも多くある。個々の事例によってその背景等は様々 であり、文化財の耐震補强においては、それぞれの事例においてど ういった背景があったのかが重要である。

この章では、意思決定の流れにおける各段階（全１3段階）にお ける要望・問題点を洗い出した。その結果、問題点として挙がった 項目の中には、もっと早い段階で検討可能な問題も多いことがわ かった。これらをもとに、生じうる問題を極力減らす為に、事前に 確認しておくべき項目、検討すべき項目をまとめておく必要がある。

また、できるだけ早い段階で様々な問題点を检討できるようにす る為にも、多くの主体間で文化財に対する意見をより広く竓論する 場を作ることが大切であり、その際に各主体がどのような姿勢で耐 震補強に臨むべきであるか、を整理しておくことも必要である。

\section{4. 耐震性能について}

\section{4-1. 耐震睃断と構造解析の手法}

各事例における耐震診断の方法は以下の 3 種類であった。

・壁量による診断

・外力と構成部材の耐力による診断

・変形量による謋断

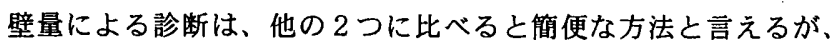
単独で用いられる事はなく、必ず他の手法と併用されていた。この ことから、壁量による検討のみでは、耐祳性能の検討には十分では ないと考えられていることがわかる。他の 2 つはコンピュー夕によ る立体架構解析であった。
可能な限りこれらの全てについて检討する事が望ましいが、建物 の構造上適さない場合もあるので、その建物に合わせた手法の選択 が重要である。今回の調查においては、後者 2 つのどちらかの手法 は必ず用いられていた。この事から、コンピュータを使用した立体 架構解析が中心となっていることがわかる。

\section{4-2. 耐震性能の目標値}

重要文化財建造物は建築基準法の適用除外となるが、できる限り これを満足することが望ましいと考えるのが一般的であ万う。しか し伝統的木造建策においては、基準法の定める変形制限の $1 / 120$ と いう首間変形角値を満足させることは難しい。補蚛案の検討を行つ た 28 事例中、変形量による検討を行った建物は 20 件あり、変形 角の許容值としては $1 / 50 や 1 / 60$ といった值を設定していた場合が ほとんどであった。 $1 / 120$ を設定した建物は 4 件に留まり、そのう ち概補強案が $1 / 120$ 以内を満たしたものは 3 件であった。

これらの結果より、基準法と同等の耐震性能を確保することは、 容易ではないことがわかる。目標值の設定については、個々の事例 において十分な検討が必要である。

また、設定した許容值を大きく上回る結果となった事例もあった。 特に震災後間もない時期の事例では、まだ文化財建造物の耐震補強 が一般的でなかったという背景もあり、補強可能部位には出来る限 りの補強を施した結果、過剩な補強となってしまったものもあった。 許容值を設定する目的は、最低限の補強で十分な強度を確保するこ とにあるので、大幅な耐カアップを図ることによって、文化財的な 価值を大きく損なうことがあってはならない、という点に留意した 構造設計が必要であるといえる。

さらに、変形角の許容值という具体的な数字よりは、「人身事故の 防止」「物的損傷の防止」「経年劣化の防止」「重量の軽量化」「二次 災害の防止」といった事柄が、耐震性能の目標を定めるに当たうて より重要視されていた。

\section{4-3. 補强を行っていない事例}

今回調查を行った事例の中で、最終的に補強を行わなかったとい う事例は全 33 件中 6 件あった。そのうち基準法の許容值を満たし ていたものは 2 件に留まった。また、基淮法の定める $1 / 120$ 以内は 満たしていないが目標値は満足していたものは 3 件あり、目標值は 満たしていないが、様々な条件に基づいた判断と研究実験の一琹で あるという背景により補強はしないことになった事例も 1 件あった。

このことからも、文化財の耐震補強においては、最大応答変位の 予測值が、建築基準法における限界変形を超えないという点のみで 判断するのではなく、文化財的な価值の維持と活用時の安全性確保 の観点に基づき、専門家の意見を採り入れて、地震災害時に許容さ れる被災程度によって判断することが要求されると言える。

\section{4-4. 各事例における補強の方法}

補強方法としては主に 6 種類あり（表 7 ）、基本的には「耐震要素 の增設」を目的としていた。次いで、「部材の補強」「部材接合部の 補強」「重量の軽量化」「柱を地盤に固定」「地盤改良」等がみられた。

表 7 補强の方法（対象事例：27)

\begin{tabular}{|l|c|}
\hline \multicolumn{1}{|c|}{ 補強の方法 } & 硋当数 \\
\hline 酎震要素の増設 & 25 \\
\hline 部材の補強 & 8 \\
\hline 部材接合部の補強 & 8 \\
\hline 重量の軽量化 & 6 \\
\hline 柱を地盤に固定する & 5 \\
\hline 地盤改良 & 1 \\
\hline
\end{tabular}


4-5. 実験に対する考え方

実験を伴った事例は 7 件で、その内容について整理した。（表 8 ）

表 8 実験内容と試倹体の有無、実験時期（対象里例：7）

\begin{tabular}{|c|c|c|}
\hline 実験内容 & 試硂体 & 時期 \\
\hline 既存の下見板の耐力試験 & $x$ & - \\
\hline 岑素綨維による仕口部分の補強効果の確認試験 & 0 & (8) \\
\hline 新旧材・木材強度試験 & 0 & (8) \\
\hline 土壁強度実験 & $\mathrm{O}$ & (8) \\
\hline 事前調查 & - & (2) \\
\hline アンカーの埋め込み長さ試験 & $\mathrm{O}$ & (8) \\
\hline 地盤調査・常時微動計測 & - & (2) \\
\hline 振動実験 & 二 & (8) \\
\hline 娻瓦強度試験 & 0 & (3) \\
\hline
\end{tabular}

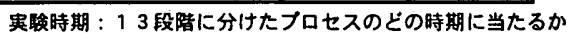

実験に関して重要なのは、「試験体の提供」「実験時期」であった。 試験体といえども文化財である、という理由で提供されない場合も あるようだが、その後のほかの事例においては試験体の提供を受け ていた事がわかった。この調査から構造設計者の多くは早い時期に 実駼や強度試験を行っておきたいと考えている事が明らかになった。

また、構造設計者が事前調查に自ら関わっている事例もあり、必 然的に現場に行く回数も增えて、現状把握や意思踈通などを十分に 行うことができていた。特に事前調査が可能であると、現状把握を する上で非常に有利となるので、構造設計者がこのような細部の段 階まで関わることができるのが理想的といえる。

一方、実験の時期が遅く、構造設計者としてはもっと早い時期に やってもらえると検討がし易かったという事例もいくつか見られた。 構造設計者の中には、実際に強度試験等を行ってみたいと考えてい た人も多く、また、自分の設計した補強の効果を確認する意味でも、 補強前後の常時微動測定に対する熱心な要望もみられた。

\section{4-6. 伝統構法の性能}

伝統構法を用いた文化財の構造解析には様々な困難が伴い、その 都度様々な仮定を用いなければならないのが現状である。構造設計 者としても、仮定にはどの程度の信頼性があるのか疑問であるので、 実際に実験をしてみたいといっだ意見も挙がっていた。

伝統木造建築にはまだ不明な点は多く、解決していくべき問題は 非常に多いと言える。今後は、伝統構法の材料や部分に関するデー 夕など様々な情報を蓄積していくことが必要であり、加えてそれら を構造設計者が共有できる体制を構筑していくことが必要であろう。

\section{5. 全体を通しての諸問題}

意思決定における流れの中において、構造設計者が設計を進めて いく上で重要なポイントとなる点が、調查によって明らかになった。 それらを以下に挙げ、検討を加える。

\section{5-1. 解体前調查の有無}

耐震診断を行うに当たり、どの構造設計者もまず解体前の建物を 見たいと考えていた。実際に建物の建っている状態を見ることから 得られる情報は、解体後に比べてはるかに多く、継ぎ手・仕口など の部材の実際に組まれている状態を見なければわからない、といつ たことも多いからである。

しかし、建物の解体には時間がかかってしまうため、設計の発注 と実際の設計との間には時間的差異が生じることになり、必ずしも 構造設計者が解体前の状態を見ることが出来るとは限らない、とい うことがわかった。
調査結果によると、全 33 件のうち解体前に見ることができな かったものは 9 件であった。そのうち、解体中であったものは 2 件 で、逆に解体部材の様子さえも見ることができなかったものは 3 件、 現地に行っていないというものが 1 件であった。解体前に見ること のできなかったものは震災直後の事例に多く、最近の事例ではこの 点についての発注者、構造設計者ともに意識が高くなってきており、 改善傾向が見られることがわかった。

表 13 解体前調查の問題点（対象果例：33、䀭当平例 : 9)

\begin{tabular}{|l|c|}
\hline \multicolumn{1}{|c|}{ 問題点 } & 該当数 \\
\hline 解体前に建物を見ていない & 9 \\
\hline 解体途中から建物を見た & 2 \\
\hline 解体部材の様子を見ていない & 3 \\
\hline 現地を見ていない & 1 \\
\hline
\end{tabular}

\section{5-2. 現場打ち合わせ回数}

各事例において、各構造設計者が現場で打ち合わせを行った回数 を調査したところ、事例によって様々であることがわかった。また、 回数とその理由には、およその傾向があることがわかった（表 9 ）。 表 9 現場打与合わせ回数と主な理由（対象淢例：33）

\begin{tabular}{|c|c|l|}
\hline 回数 & 件数 & \multicolumn{1}{|c|}{ 主な理由 } \\
\hline $0 \sim 3$ 回 & 11 & 霞災後間もない、施工監理に携わっていない \\
\hline $4 \sim 6$ 回 & 9 & 現場まで遠いなど回数が限られている \\
\hline 10回〜 & 13 & できる限り行っている \\
\hline
\end{tabular}

この結果より、現場が遠いために、ある程度行く回数が限られて しまうという事例も多くあることがわかった。現場が遠いという背 景は、「文化財建造物の耐震補強」という特殊な経験のある事務所が まだ少ないことも一因となっており、これから解決していくべき問 題のひとつである。

調査結果より、構造設計者が実際に現場へ足を運ぶことには重要 な意義があると考えられる。それらは大別すると次の 2 点である。

〈建物の現状把握〉

図面に表れる情報はごく一部なので、現場を見ることが最もよい 方法であり、工事における各段階で、タイミングよく構造設計者が 建物の状態を見ることが大切である。

<各主体間の意思疎通 $>$

施工関倸者と現地でよくコミュニケーションをとることが重要で ある。また、実際に現場を見ながら各主体と検討することによって、 より密な検討が可能となるので、各主体間での意識の差異を埋める という点でも、現場を見ながらの検討が一番よい方法である。

以上のこれらの点から、構造設計者も可能な限り現場へ足を運ぶ ことが望ましいといえる。

\section{5-3. 補强案の提案数}

各事例における補強提案数を整理した（表 10）。部位別にそれぞれ 提案数が違うものもあったので、それらは別々に分類した。

表 10 補强提案数（対象事例 : 28、パターン数 : 30 )

\begin{tabular}{|c|c|c|c|c|c|}
\hline 提案数 & 1 案 & 2 案 & 3 案 & 4 案 & 5 案 \\
\hline 事例数 & 17 & 2 & 8 & 2 & 1 \\
\hline
\end{tabular}

この結果より、提案数が 1 案のみであったもの（17 例）と複数 案のもの（1 3 例）とではほほ半数ずつとなっていた事がわかった。 しかし、事例が新しくなるほど、補強提案数が 1 案のみのものが多 くなってきている傾向が見られた。一方で、構造設計者としてはで きる限り多くの案を出したい、という意見も挙がっていた。

補強案の提案数が 1 案のみであったものの背景には何があるのか、 調查結果をもとにまとめると以下のようになる。 
〈問題点がはっきりしていた >

・「何を残したいのか」などの明確な提示が事前にあったことに よって選択肢が限られていた

・設計監理側からはっきりとした問題点の提示があった

・その方法でしか補強案が考えられなかった

〈構造設計者が文化財の耐震補強に慣れてきた〉

・どういった補強をすればどの程度の効果があるのか、という ことに、ある程度予測がつくようになった

・設計監理側との意思柾通方法が円滑になったことによって、 事前に案が絞られた

特に、構造設計者が慣れてきたことで、様々な主体間での検討を 行う前に「事前に案が絞られた」ことによって、提案数が 1 案のみ になってしまうことがあるという点については、必ずしもよいとは いえない。なぜなら、補強案の検討については、一度関係者を広く 集めた場での検討があった方が、様々な要望や助言を受けられるか らである。こういった場において複数案を検討することによって、 より良い補強案を作成でき、さらに、後に生じる可能性のある問題 を少しでも回避できることになる。補強方法決定までのプロセスを 円滑にすることも大切であるが、ある程度の段階での広く議論を行 う場を設けることも必要であるといえる。

構造設計者の立場からみても、やむを得ない理由から他の補強案 を考えることが出来ないような場合を除いては、出来る限り複数案 の提案を行い、それぞれの事例によって様々な可能性の検討を行う ことが望ましいと考える。

\section{5-4. 施工後に生じた問題点}

施工後に生じた問題点としては以下の 2 点が挙げられる。

・設計監理側の図面に間違いがあり変更箇所を構造設計者が知 らないまま設計を行った結果、補強が一部見えてしまっていた ・所有者が文化財の補強部分に関してあまり気に留めておらず、 むしろ「立派になった」という意識があったこと、一般公開す る予定だった部屋は日常使う部屋なので展示したくなく、公開 しないはずの、鉄骨補強が露出している物置を見学者に公開し てしまっていた

これらの問題点は、特に歴史有識者達にとっては大問題であり、 主として各主体間の意思疎通の不足に原因があったと考えられる。 これより、他の主体との意識の違いや意思蹯通の難しさを箱うこと ができる。

\section{5-5. 意思決定の進行における各主体の関わり}

これまでの調査で、構造設計者がどのような主体と関わりがあっ たのかは、意思決定に大きく影響してくる重要なポイントであるこ とが明らかになった。ここでは、構造設計者が実際に検討する場を 持った主体との関わりを整理し、右の図 2 に示す。

<有識者〉

構造専門家や歴史専門家等の有識者からの有益な助言によって、 補強案に影響のあった事例も多く見られた。

\section{$<$ 所有者>}

所有者は、個人・団体である場合と、市町村などの行政機関で ある場合があった。特に、所有者が個人である場合については、今 回扱った事例では、ほとんどの場合で何らかの要望が生じていた。 結果として、それらの要望を優先させる形で補強案が決まっていた ことから、所有者の要望の重要性が䇲える。

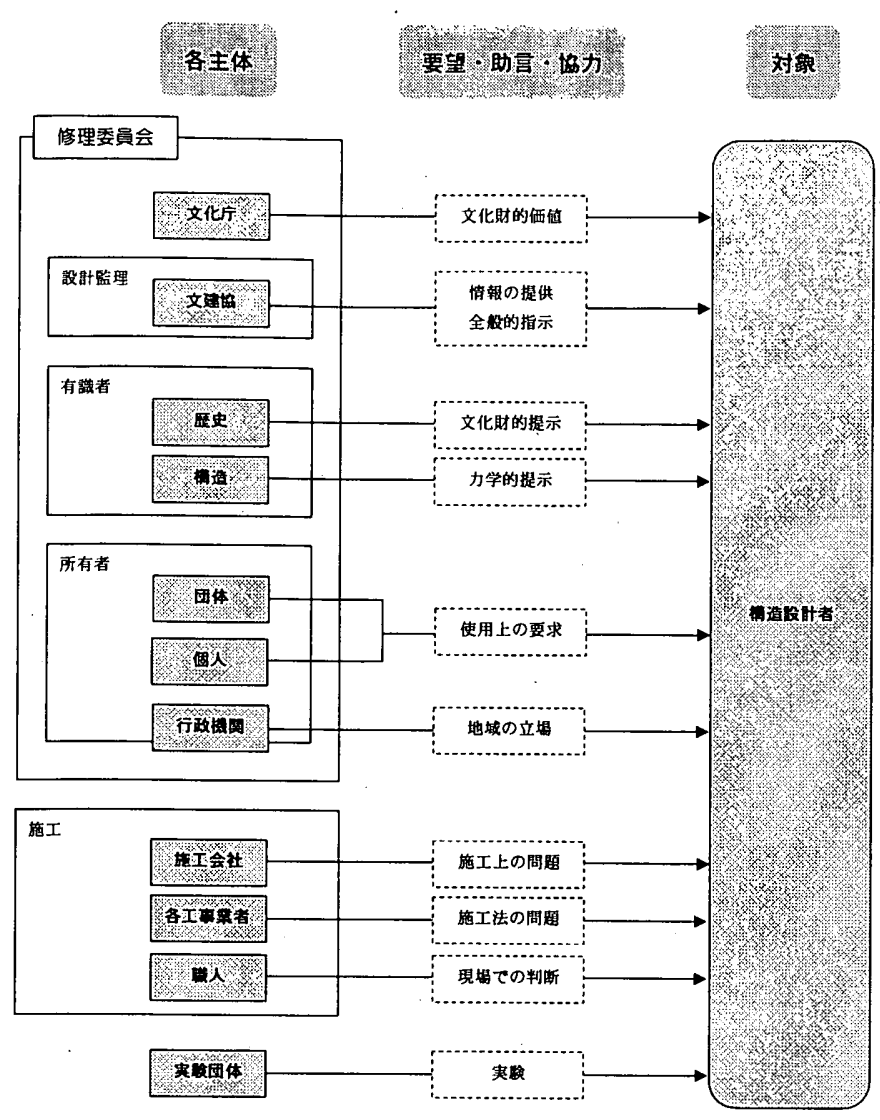

\section{図 2 各主体から搆造設計者への関わり}

\section{<施工関係者 $>$}

施工会社をはじめとして各種工事業者や現場の職人と検討の場を 持った例もいくつかあった。施工段階での問題点も多くあったこと から、これらの主体との積極的な関わりも重要であることがわかる。

\section{5-6. 各主体間の意識の差}

構造設計者とは異なった価值観を持つ各主体との間には、意識の 差異が生じることがあった。意識の違いの例を、以下に挙げる。

〈構造設計の立場と歴史・保存の立場の間〉

・文化財でない部分の扱い（構造的に残したい@撤去したい）

・試験体の提供（提供して欲しい@提供できない）

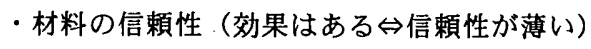

〈構造設計の立場と施工関係者の立場の間〉

・接合方法（ボルトは避けたい@確実な方法で）

- 文化財建造物の施工に対する意識（高い@あまり高くない） 〈歴史・保存の立場と所有者の立場の間〉

・補強部の公開（公開したくない@気に留めていない）

これらの例より、構造設計者が設計監理者と意思疎通を図ること はもちろんであるが、その他の主体との関わりも重要であることが わかった。前述したように、構造設計者と、所有者や施工関係者と いった主体との意識の差異が問題となった事例もあることから、こ れらの主体も含めて、耐震補強について広く議論する場を設けるよ うにしていくことが今後必要であるといえよう。

ここまでにわかったプロセス上のポイントを次の図 3 に示す。 


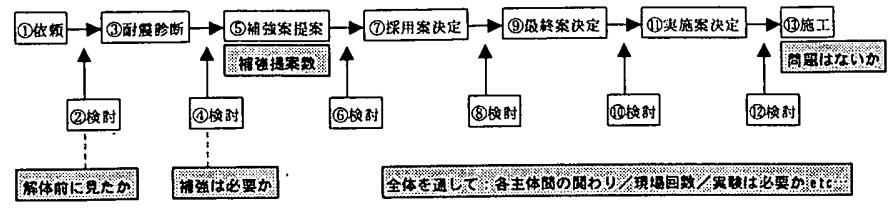

图 3 プロセス上のポイント

6. 結論

分析結果より、もっと早い段階で検討可能であった問題等を中心 として、事前に検討しておくべき項目が明らかになった。それらを もとに、各段階における検討事項、参加すべき主体、各主体の役割 等について、木造文化財建造物の耐震補強工事をする上で生じうる 問題を極力減らす為に構造設計者が他の主体と各工程において行っ ていくべき検討項目をプロセスの流れに沿って提案する。（表 16）

施工中や施工後に生じる問題は極力避けたい。また、それらの問 題は事前に対策可能なものが殆どであるため、ここでは調查によっ て明らかになった問題点は、問題が生じていたより前の段階での検 討項目に組み込んである。

〔3-2. 実施設計段階の(12)段階で挙げた〈事前に検討可能な項目〉】 について、例えば、 $\mathrm{a}, \mathrm{b}$ の接合部の問題は、補強案を 1 案に絞り込 む(6)段階で具体的工法を決定する際に検討しておくと、より良い方 法を選択でき、実際の施工時に作業が円滑になる。また、 c, d, e, f の部材の大きさの問題と地中埋蔵物の問題は、初期の現状把握をす る(2)段階で、周辺環境を把握する時に確認しておける事柄である。 部材の規模や置場に関しては、補強案が決定しないと確認し得ない 事柄であり、その段階での確認は当然為されるという前提で、ここ では逆に、早い段階で部材置場の大きさと状況や、どのくらいの規 模の補強材や仮設資材、または施工機械等が搬入可能か、という事 をある程度確認・把握しておくことによって補強計画を立てる上で の目安となるので、(2)段階での確認を提案している。実際に、工事 が始まってから部材が現場に運び込めずやむなく切断して搬入した り、既に決定した工法や補強方法を施工開始後に変更したりした例 が 4 件あった。さらに g の結露の発生する可能性のある部位の対策 については、6段階の、補強方法や、その具体的工法を決定する時 に、共に検討しておける事項であろう。

さらに【5-5. 意思決定の進行における各主体の関わり】と【56. 各主体間の意識の差】、の中で述べた事柄の中で、基本コンセプト に関する各主体間で話し合うべき項目は(2)段階の検討項目 3 に、ま た、材料・部位レベルでの各主体間での検討すべき項目は(4)段階の 検討項目 7 に組み込んだ。

逆に、補強部に文字が書かれてあったり見えない部分の基礎レべ ルが下がっていたりといった、建物解体後はじめて明らかになる事 柄もある。さらに、最終的な「あきらめる」という判断を行う、決 定した方法を施工業者が本当に施工できるのか確認する、材料サイ ズの最終的な確認をする等といった項目を(8)段階の検討項目 10 に組 み込んだ。遅くともこの段階までには、建物の解体を始めつつ、そ の状況をもとに最終補強案を決定する方法が望ましい。

また、リスト上の(13)段階の「現場でのコミュニケーション」とは、 調査を進めて必要性が高いと感じた事柄である。構造設計者も可能 な限り施工監理まで携わることが望ましく、なぜなら施工関係者に 直接自分の設計の意図をはっきりと伝えることができるという意義 があるからである。施工側から見ても、文化財の修理・補強工事の 経験があまり無いことが原因で生じうる意識の差異を埋めるために も必要なことであると言える。
7. 今後の課題

今回、震災直後のものから最近のものに至るまで多くの事例につ いて調査を行った結果、各事例における様々な背景や、各事務所に おいて徐々に確立されつつある文化財建造物の酎震補強設計の進め 方が明らかになった。ただし、本研究は構造設計者からの視点を中 心として進めてきたので、耐震補強に関わる他の主体からの視点に ついて述べるものではなく、その意味で限界があると言える。

また、文化財の耐震補強に対する考え方は各構造設計者によって 様々で、それぞれの特徴が解析手法、目標值の設定、取り組み方等 に表れていた。「文化財を護りたい」という気持ちは共通している が、その表れ方がそれぞれ違うのである。技術面でも、今後は構造 設計者が考え方や技術を共有していくことが重要で、新たに耐震補 強を手がける主体のためにも必要なことである。

これまでの分析で明らかになった今後への課題を以下にまとめる。 く設計監理側に関わる課題〉

伝統構法における様々なデータの蓄積・共有化

・各主体が広く議論できる体制を作ること

〈構造設計者に関わる課題 $>$

・而震性能の目標值についての十分な検討

・解体前には必ず建物の状態を見ること

・できる限り現場へ足を運ぶこと

- 複数案の提案/様々な可能性の検討

〈镁辞〉

本研究は、科学研究補助金 (課題番号 12878096)の助成を受けました。また本調查 の実施にあたって、多くの企業・団体等の関係者の方々に、資料提供、ヒアリン ク等、多大なこ協力とご助言を頂きました。ここに記して深謝申し上けますす。 〈注释〉

注1）本稿における「主体」とは、重要文化財建造物の耐震補强設計に関わる設計 監理者、構造設計者、所有者、構造・歴史の有撞者等の関係者を指すこととする。 〈関連研究〉

1) 園田雄获, 角陸順香, 藤田香織, 清家剛 : 木造重要文化財建造物の螣造補強工事 における意思決定プロセスに関する研究, 日本建築学会大会学術謴演梗概集, $\mathrm{E}-1$, pp. $683-684,2001.9$

2) 宇野䋨晴 : 木造重要文化財建造物の耐振補強に関する研究一構造設計者へのヒアリ

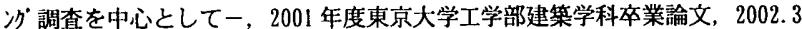

3）角陸順香, 清家㴊, 藤田香織, 宇野䋛晴: 木造重要文化財建造物の耐震補強に関 する研究一その 1 各段階での恰討内容の分析一, 日本建策学会大会学術講演梗概 集, E-1, pp. 597-598, 2002.8

4）宇野結晴，清家剛，藤田香織，角陸順香：木造重要文化財建造物の耐震補強に関 する研究一その 2 耐震性能および諸問題の分析一, 日本建築学会大会学術講演梗 概集, E-1, pp. 599-600, 2002.8

5）清家岡 : 耐震性を考虑した糜史的建造物の保存・再生における意思決定プロセス 研究, 2000-2002科学研究補助金研究成果報告書, 2003.3

6）角陸順香，清家剛，藤田香織，宇野䋛晴：木造重要文化財建造物の耐震補強に関 する研究その 1 各段階での検討内容の分析, 日本建策学会関東支部研究報告集 II, pp. 57-60, 2003. 3

7) 角陸順香, 清家剛, 藤田香織, 宇野總晴 : 木造重要文化財建造物の耐震補強に関 する研究その 2 而震性能および諸問題の分析, 日本建築学会関東支部研究報告 集 II, pp. 61-64, 2003.3

〈参考文献〉

a) 文化仃文化財保護部:重要文化財（建造物）耐霞診断指針， 2000.3

b) 文化庁文化財保護部:重要文化財（建造物）耐震診断指針参考資料集，2003.3

c）安田一男、藤田香織、木村正彦他 : 伝統的木造建築の壁体に関する振動台実験 その $1 \sim 3$ ，日本家勧学会大会梗概集，pp. 147-152,1997.9

d）坂本功、木村正彦他：伝統的木造建勧の組物の振動台実験その $1 、 2$, 日本家 学会関東支部研究報告集, pD. 37-44, 1998. 3

e) 藤田香䋘、木村正彦、他 : 伝統的木造建築の組物の振動台実験その $3 \sim 7$, 日本 家策学会大会梗概集, pp. 263-266/159-160/147-148/171-172, 1998. 9 2001.9

1) 前川秀幸他 : 文化財建造物の常時微動測定と古民家の構造特性, 重要文化財（建 造物）耐据祅断指針 参考資料集，pp. 17-30, 2000.3

g) 西澤英和他 : 実台茶室の振動実験，重要文化財（建造物）耐震診断指針 参考資 料集, pp. 67-75, 2000.3

h) 加藤邦男他 : 文化財建造物の耐霞的保存方法に関する研究, 1997.3

i）坂本功：木造建筑を見值す，岩波書店，2000.5

j）財団法人文化財建造物保存技術協会 : 修復の手帖, 文化財保護法 50 周年記念協 賛事業実行委員会 2002.8

k）木村勉：近代建筑解体新書一修復の計画と技術，中央公論美術出版，1994.3 
表 16 木造重要文化財建造物 耐震補強チェックリスト

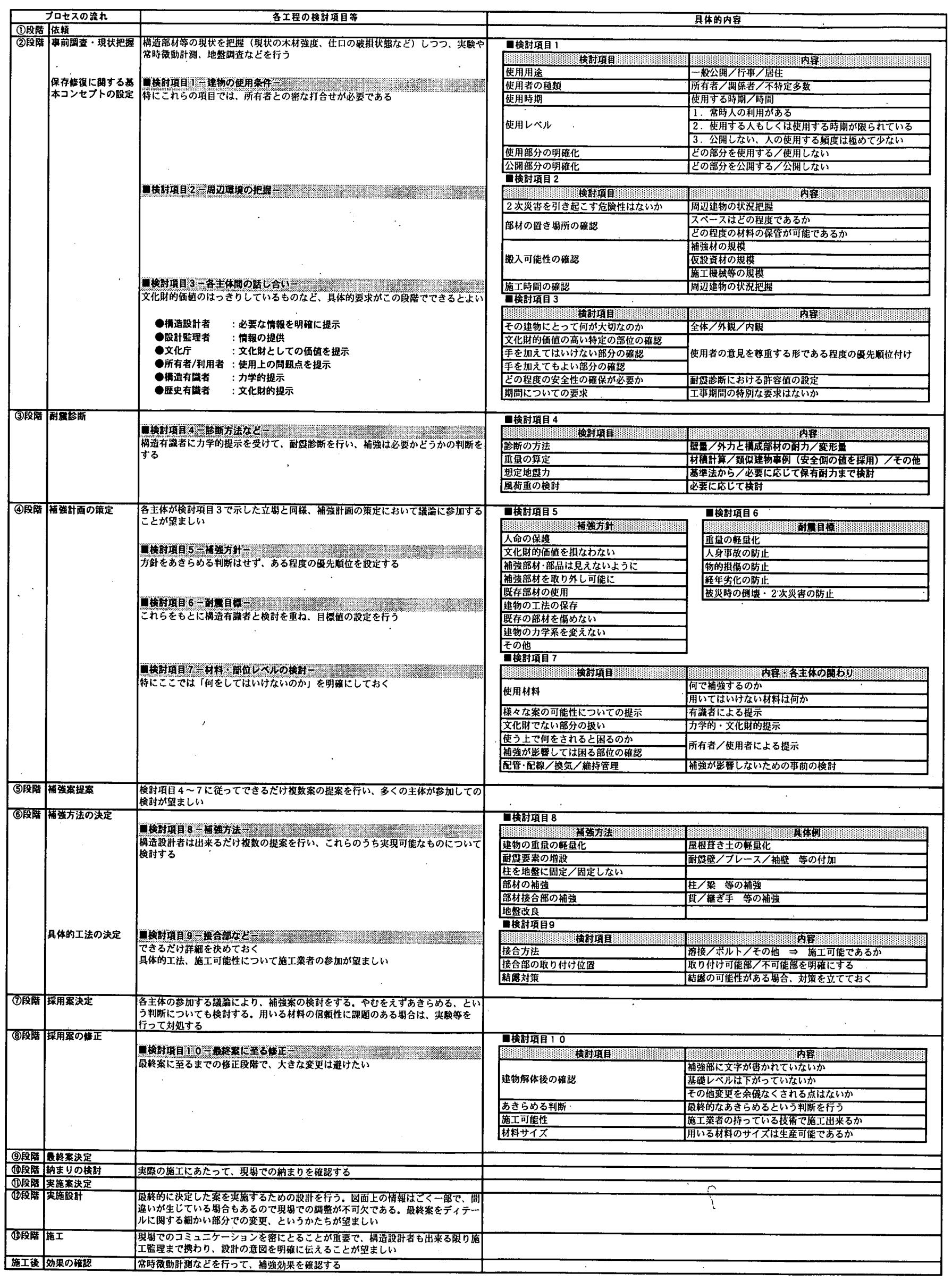

